\title{
Religiosity and Bank Asset Securitization
}

\author{
Omneya Abdelsalam ${ }^{a}$, Marwa Elnahass ${ }^{b}$, and Sabur Mollah ${ }^{\text {1 }}$ \\ aDurham University, UK

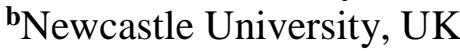 \\ ${ }^{\mathrm{c}}$ University of Hull, UK
}

\section{Acknowledgement:}

We acknowledge the financial support for this project from El Shaarani Ethical Finance Research Centre at Durham University and Jan Wallanders och Tom Hedelius Stiftelse, Handelsbanken, Sweden (Project ID: P2010-0144: 1). We also thank Antonios Chantziaras, Ioanna Baltira, and Ammar Elkhatib for research assistance in data collection. The authors thank Professor M. Shahid Ebrahim, Professor Jullian Williams, Professor Habib Ahmed, Professor Iktekhar Hasan, and the participants of the Surrey - Fordham Conference on "Banking, Finance, Money and Institutions: The Post Crisis Era", November 2-3, 2013, for their valuable comments. We are thankful to Shaokang Wang for discussing this paper at 2014 Financial Innovation and Bank Regulation conference, Xiamen, China, December 19-20, 2014. We also benefitted from the comments from Ren-raw Chen, Kose John, and An Yan at the 2014 Financial Innovation and Bank Regulation conference, Xiamen, China.

\footnotetext{
${ }^{1}$ Corresponding Author: Professor Sabur Mollah, Hull University Business School, UK, Email: S.Mollah@hull.ac.uk
} 


\title{
Religiosity and Bank Asset Securitization
}

\begin{abstract}
The global financial turmoil of 2007-2008 underlines the importance of understanding asset securitization, a process that allows banks to shed credit risk, fund their credit growth, and arbitrage capital requirements. Examining this ethically questionable activity has become crucial given its perceived long-term social impact. This paper examines the factors that motivate banks' decisions to enter into asset securitization. In particular, we examine the influence of both organizational and geographic religiosity as important ethical parameters of economic choices on banks' decisions to securitize their assets. We employ propensity scores using a unique database on asset securitization of banks in 22 countries during the period of 2003-2012. We find that both types of religiosity indicators are significantly associated with banks' decisions to securitize. Banks located in countries with high religious importance scores show a lower likelihood to securitize. We also find that religiously adhered banks are likely to embark on a constrained model of securitization, which involves a high level of monitoring. In addition, our analysis suggests that religiously adhered banks are less likely to engage in asset securitization to reduce credit risk by shifting it to new investors. This conclusion is supported by their lower credit risk in the years before securitization. Alternatively, our results suggest that these banks embark on asset securitization to improve their financial and regulatory performance. Our study emphasizes the importance of considering religiosity as an important institutional factor and a monitoring mechanism in future global banking studies. Findings in this study are of importance to researchers, to local and international regulators, and to different stakeholders in the international banking sector.
\end{abstract}

Keywords: Asset Securitization, Bank type, Religiosity, Bank Risk,

JEL Classification: C23, G01, G21, G28, L50, M41 


\section{Introduction}

With ethics being considered the bedrock of successful financial intermediation and stable financial systems, an increasing number of studies have examined their impact on economic decisions. In particular, many studies have found that firms' religiosity affects their financial behavior (see Leventis et al., 2015; Kanagaretnam et al., 2015; Dyreng et al., 2012, McGuire et al., 2012). Prior studies in ethics research argue that individuals and organizations with stronger religious beliefs are less likely to accept risky or ethically questionable decisions in a business environment (Longenecker et al., 2004; McCullough and Willoughby, 2009; Vitell, 2009). In the same vein, religiosity has been argued to induce social norms ${ }^{1}$ that foster sound moral judgment and ethical behavior in organizations (Weaver and Agle, 2002). Similar to people, religious organizations are likely to be risk averse (Osoba, 2003; Hilary and Hu, 2009). Although the impact of religious social norms on the economic behavior of organizations has been generally discussed (Callen and Fang, 2013), examinations of the influence of religiosity on contemporary bank-level decisions such as asset securitizations are lacking. Such investigation is of wide importance to regulators and market participants and answers prior calls for further research on how social norms influence bank risk (Stulz and Williamson, 2003; Acemoglu et al., 2005).

The global financial crisis of 2008-2009 raised some serious questions on the credibility of certain innovative financial tools such as asset securitization, and it highlighted the dangers of undermining the ethical foundation of financial systems (McConnell and Buser, 2011; Gorton and Metrick, 2012). During the last two decades, asset securitization ${ }^{2}$ has gained momentum, reaching volumes of $\$ 10.24$ trillion in the United States and \$2.25 trillion in Europe by the second quarter of 2008 (Barth and Landsman, 2010). However, this innovative tool has been blamed for playing a major role in the instability of the global financial markets in the 2008 financial crisis.

\footnotetext{
${ }^{1}$ Social norms are defined as attitudes of approval and disapproval (Sunstein, 1996). Religion has a substantial role in shaping and enforcing ethical behavior, including honesty and justice.

${ }^{2}$ Securitization is the financial practice of pooling types of contractual debt (or nondebt assets that generate receivables) and selling consolidated debt (or receivables) to third party investors as securities. The principal and interest on the debt, underlying the security, is paid back to the various investors regularly. Securitization has been applied mainly by financial institutions to expand their loan portfolios to offer new loans to lower income groups, accessible to subprime consumers (DeLorenzo, 2007; Totaro, 2009). In the United States the market for securitizations counted on two important assets: asset-backed securities (ABS) and mortgage-backed securities (MBS). Both types of debt contracts have played a crucial role in integrating securitization markets. MBS are securities created from the pooling of mortgages, which are then sold to investors. They have been developed by means of government-sponsored agencies (such as the Federal National Mortgage Association, known as Fannie Mae, and the Federal Home Loan Mortgage Corporation, or Freddie Mac). The demand for these types of securities grew rapidly among institutional investors who were willing to invest in credit risk (Bowden and Lorimer, 2009; Campbell et al., 2011; Casu et al., 2011). These types of securities are prohibited in Islamic banks because they involve paying interest and the sale of debt.
} 
Asset securitization decisions represent either risk-taking and/or risk-shifting decisions, which can be profitable but ethically questionable activities. Asset securitization is based on converting the promises of future payments into freely transferable securities (Davidson, 2003). This activity enables financial institutions to make nonmarketable assets marketable and eliminate these assets from their balance sheets by selling them to special vehicle entities and then to new investors (Zöngür, 2010). In principle, asset securitization should allow credit risk to be redistributed to investors who can bear it, which should facilitate the functionality and stability of financial markets (Buchanan, 2015). However, this innovative activity has not followed ideal principles. Securitization has enabled banks to convert illiquid assets into liquid funds, but it has reduced their incentives for due diligence, leading to expansion of credit. It has also caused banks to hold riskier assets. Asset securitization was blamed for containing perverse incentives for banks to lend and quickly package those loans to transmit the credit risk to third party investors. This activity impaired the issuing banks' financial condition and increased both their credit and systematic risks (Calomiris and Mason 2004; Cebenoyan and Strahan 2004; Loutskina and Strahan 2006; Haensel and Krahnen, 2007; Purnanandam 2009; Casu et al. 2013). In addition, the inherent complexity and limited monitoring ability of this model led to a major decline in underwriting standards, ${ }^{3}$ which brought about the severe subprime crisis that triggered a bitter financial crisis ${ }^{4}$ (Kiff and Kisser, 2014).

After the global financial crisis, asset securitization became ethically questionable because of its low incentives to appropriately screen borrowers (Loutskina and Strahan, 2009; Keys et al. 2010) and its high incentives to securitize low-quality assets and shift the credit risk to new investors (Dell'Ariccia et al. 2009; Mian and Sufi, 2009; Keys et al., 2010). Elucidating the practices underlying banks' securitization activities, especially their motives to securitize, became a crucial issue in the research on financial institutions, which is the objective of the current study. In particular, we examine the influence of both organizational and geographic religiosity as important ethical parameters of economic choices on banks' decisions and motives to securitize their assets.

This study is the first to examine the decisions and motives of asset securitization in the global

\footnotetext{
${ }^{3}$ For example, the SEC filed allegations against Goldman Sachs for opportunistically designing synthetic collateralized debt obligation (CDO) using mortgage-backed products, which had long-term adverse implications on the credit ratings of securitized loans (World finance, July/August, 2010). This had been viewed as a wrongful act in the flawed securitization process, which brought unfair practices of the current financial regime.

${ }^{4}$ Ethical commentary on the reasons underlying the occurrence of the global financial shock referred to ultimate concepts of imprudence, greed, and recklessness, granting demand-driven loans made to unworthy borrowers (Donaldson, 2012). The financial turmoil has highlighted a failure of the beliefs, judgments, and structural design of asset securitization. It has been criticized as a flawed process, which created significant financial and credit risk shocks in the economy and consequently led to widespread subprime in the banking industry (Gorton and Metrick, 2012; Gorton, 2012).
} 
banking industry, while also accounting for cultural factors. In particular, the study examines the impact of both geographic and organizational religiosity on banks' motives to securitize. A notable feature of the global banking industry is the significant increase in the number of religiously adhered banks, which have a participatory model of finance that encourages the sharing of profits, losses, and risks. These banks operate on a constrained business model that prohibits excessive uncertainty (Beck et al., 2013; Elnahass et al., 2014; Abdelsalam et al., 2016). Religiously oriented organizations are likely to adhere to the moral constraints that shape the particular context of their economic operations. These constraints are also expected to mitigate risk shifting and to promote a risk-averse attitude. ${ }^{5}$ In addition, communities in which religion is important hold expectations that shape individuals' behavior (Weaver and Agle 2002). Attitudes in these communities are, to a certain degree, shaped by the endorsed behaviors. Such influences are pervasive in geographic locations where religious adherence (RA) is a predominant characteristic of the local population (Boone et al. 2013; Callen and Fang 2015; Chourou 2013; Dyreng et al. 2012; Grullon and Kanatas 2010; Hilary and Hui 2009; Kumar et al. 2011). Accordingly, religiously adhered banks and communities in which religion is highly important are expected to show a distinct profile of risk taking as well as distinct motives for asset securitization. This study uses unique, comprehensive hand-collected data for global asset securitization activities in 22 countries for the period 2003-2012. Empirical tests employ propensity score estimation for panel data from 672 global banks (4889 bank-year observations). Propensity Probit analyses make comparisons between banks involved in two types of decisions related to asset securitization: (a) banks that enter into a securitization activity for at least one year and (b) banks that never enter into a securitization agreement. Apart from several bank and country controls, we have determined six major firm-level drivers (motives) for asset securitization decisions. Bank motives include (a) regulatory capital adequacy, (b) credit risk, (c) cost efficiency, (d) operating income, (e) loan concentration, and (f) loan growth rate. We utilize two indicators for religiosity representing geographic and organizational measures: (a) a country-level proxy for the high (low) importance of religion to individuals, and (b) an organizational religiosity measure for bank type (religiously adherent or conventional bank).

Our results show that religiosity has a significant influence on banks' decisions to securitize. We find that banks located in areas with high geographic religiosity are less likely to securitize, which is an indication of risk aversion. In addition, results show that banks with RA are more likely to

\footnotetext{
${ }^{5}$ According to Kaptein (2011) and Ha-Brookshire (2015), in corporations with well-defined moral guidelines or structures that all members can easily follow, the morally responsible behavior of individuals within the corporations improves.
} 
securitize but only use a highly constrained model of asset securitizations to meet their liquidity challenges without violating their religious constraints. Additional testing within subsamples consistently show that banks located in highly religious geographic locations ultimately use securitizations to improve their financial performance and loan portfolio diversification. However, banks located in areas with low levels of geographic religiosity show a high credit risk profile, which implies substantial motives to use asset securitizations for risk shifting. RA banks, representing organizational religiosity, use a constrained model of asset securitizations that is likely motivated by a need for improving capital adequacy requirements and promoting loan growth. These banks show a notably low credit risk, which indicates that risk shifting is not a driving motive for asset securitization. This finding also implies that RA banks ultimately use their constrained securitization model to lower the cost of funding through diversifying their income and loan portfolio. However, conventional banks show a high credit risk profile despite having high cost efficiency, implying that their securitization decisions are more likely to be motivated by shifting risk.

Findings in this study are in line with social norms theory and highlight the important role of religiosity in constraining risk-taking and risk-shifting behaviors, both of which may be considered ethically questionable. Our study contributes to the current literature in several ways. Our analysis extends previous findings that religiosity acts as a monitoring mechanism that influences behavior and investment choices at the firm level (Hilary and Hui 2009; Boone et al. 2013; Callen and Fang 2015; Dyreng et al. 2012; Kumar et al. 2011 Kanagaretnam et al., 2015). We shed light on how religiosity may serve as a monitoring mechanism that reduces agency costs in an organization, which is an important issue to stakeholders and regulators of the banking industry worldwide. This finding extends research on the association between financial decisions and RA (Dyreng et al. 2012; Grullon and Kanatas 2010; McGuire et al. 2012; Leventis et al. 2015). In addition, our results expand on prior analyses on the financial determinants of asset securitizations and corporate policies (e.g., Haensel and Krahnen, 2007; Mian and Sufi, 2009; Affinito and Tagliaferri, 2010; Casu et al., 2013) and thus extends our understanding of the global banking model. We provide empirical evidence to support previous discussions in the literature about the role of asset securitization in shifting the responsibility for handling risk in the banking industry and its ethical consequences (Buchanan, 2015). In this sense, our findings draw the attention of regulators and policy makers to the morality of risk-shifting motives in conventional asset securitization activity, stressing the need for regulatory scrutiny to prevent another wave of global financial crises.

The next section discusses the related literature and develops the hypotheses. Section 3 presents 
the study sample and data. The methodology and model are covered in section 4. Descriptive and empirical results are presented in section 5, which is followed by the conclusion in section 6 .

\section{Motives of Securitization}

It should be noted that banks might have more than one underlying motive for being involved in asset securitization. Prior studies identified several motives, such as improving regulatory capital adequacy, shifting credit risk to new investors, diversifying loan portfolios, and improving profitability (see Pavel and Phillis 1987; and Hess and Smith 1988). In theory, these benefits are expected to help banks operate at a competitive advantage, while lowering their cost of debts (Rosenthal and Ocampo, 1988). However, mixed results are observed in practice. Bannier and Ha"nsel (2008) suggest that securitization markets are mainly driven by credit risk management and liquidity improvement instead of regulatory capital adequacy improvement. Casu et al. (2013) find that U.S. securitizing banks have high credit risk, high funding costs, and less liquidity despite being more profitable and having a more diversified funding structure.

Prior research identifies two directions with regard to credit risk. On the one hand, the higher a bank's credit risk, the more likely is it to become involved in asset securitization to shift risk to new investors (Cebenoyan and Strahan, 2004). Prior literature shows that banks securitized their worst mortgage loans to pass their credit risks to new investors (Dell'Ariccia et al., 2009; Mian and Sufi, 2009; Keys et al., 2010). In line with Cantor and Rouyer (2000), the credit risk profile for the issuer improves if the riskiness of the securities sold to investors is higher than that of the issuer prior to the securitization. In the same vein, Purnanandam (2011) also find that U.S. banks benefited from securitizations to shift loans with a higher-than-average default risk. On the other hand, asset securitization might intensify the issuer's net exposure to the default risk of its assets. Securitization could also lead to even higher risk activities by banks operating at greater financial leverage levels. Dionne and Harchaoui (2003) find a positive association between securitization and bank credit risk. Franke and Krahnen (2005) and Haensel and Krahnen (2007) indicate that collateralized debt obligations (CDOs) increase the systematic risk of the issuing bank. In addition, Panetta and Pozzolo (2010) suggest that although securitization helps banks to improve their asset portfolio, it increases their likelihood of engaging in substantially riskier profit opportunities.

With regard to the profitability enhancement motive, asset securitization helps banks to improve their profitability position through pooling assets and issuing multiple financial claims with different risktaking characteristics. Banks can also use securitization to take advantage of increased economies of 
scale and diversification of funding sources and to improve regulatory capital (Jones, 2000). With respect to a cost-efficiency motive, Panetta and Pozzolo (2010) show that securitization help banks to improve the efficiency of both direct and indirect costs. Affinito and Tagliaferri (2010) report that banks with low profitability, low liquidity, poor capital adequacy, and high levels of nonperforming loans are more likely to securitize.

Prior research is inconclusive on the motives behind banks' decisions to embark on asset securitizations. In addition, none of the prior studies examine the impact of an important institutional factor, such as religiosity, on the underlying motives for deciding to securitize. Religiosity tends to operate as an important control mechanism that affects financial reporting and risk-taking behavior (Callen and Fang 2013). In this study, we investigate the role of this cultural and institutional factor, on both the country and bank levels, on the factors motivating banks to undertake asset securitizations.

\subsection{Asset Securitization and Religiosity}

The financial sector has generally been viewed as failing to consider the important normative dimension of who bears risk and how it should be transferred (Kolb, 2011). Financial innovations often seem opaque given the inherent risk levels that are difficult for third parties to quantify (Boatright, 2010). Asset securitization as one of the credit boom innovations is regarded as a legitimate activity, provided that the receiving parties of the transactions can handle the risk. If this link between the borrower and the lender is broken, then potential exists for an ethical problem (Buchanan, 2015). Ethical concerns are more likely to arise because of the involuntary transfer of risk to investors through the use of excessive power and deceit (Buchanan, 2015). Current practices of securitization before and after the financial crisis have shown that receiving parties are rarely aware that a risk-shifting process is occurring and hence cannot manage and handle the transmitted risk. Such strategic misinterpretations by investors makes it either unethical or not in line with social norms.

Religion, as part of social norms, plays a catalytic role in determining both the judgments and intentions for a particular situation as well as the actual individual behavior. Ethics and religiosity have long been discussed in prior literature for their effects on shaping investment choices and on individuals' values and responsibilities (Adam Smith, 1976; Weber, 1905; Barnett et al., 1996; Innaccone, 1998; Kennedy and Lawton; Lehrer 2004; Shukor and Jamal, 2013; Vitell, 2009; Weaver and Agle 2002). Religiosity is viewed as an institutionalized mechanism that promotes aversion to risk (Miller and Hoffmann 1995; Osoba 2003). It can constrain excessive risk-taking by enhancing 
internal monitoring. Therefore, engaging in securitization activities to satisfy underlying economic motives might not be ethically acceptable and is likely to be affected by the presence of strict religious norms. This prediction has been supported in recent literature that demonstrates a positive association between religiosity and individual economic attitudes like risk aversion (Leventis et al., 2015; Callen and Fang 2015; Diaz 2000; Mazar et al. 2008; McCullough and Willoughby 2009; Miller and Hoffmann 1995). More specifically, Kanagaretnam et al. (2015) find that banks located in more religious countries exhibit lower levels of risk in their decision-making compared with banks in less religious countries.

Such influences are pervasive in locations where religious adherents are predominant in the local population (Boone et al. 2013; Callen and Fang 2015; Chourou 2013; Dyreng et al. 2012; Grullon and Kanatas 2010; Hilary and Hui 2009; Kumar et al. 2011). Religious attitudes and community expectations are, to a certain degree, shaped by the endorsed behaviors in a geographic area. On a geographic or community level, self-regulated attitudes are usually widely promoted and perceived as acceptable. Religious communities usually establish expectations and create conceptual frameworks that shape individuals' behavior (Weaver and Agle 2002). Risk taking and the likelihood of accounting fraud have been found to be lower in contexts characterized by high RA compared with contexts with low RA (Dyreng et al. 2012; Grullon and Kanatas 2010; McGuire et al. 2012; Leventis et al. 2015).

Based on the preceding discussion, we expect that banks in areas with high geographic religiosity (GR) (score high on the survey of the importance of religion) prioritize ethical choices among different business opportunities that involve risk-taking decisions (Hilary and Hui, 2009) and are more risk averse (Leventis et al., 2015; Kanagaretnam et al., 2015). We also expect these banks to be less likely to engage in asset securitization activities; if they decide to pursue the activities, their motive is mainly to improve their financial performance and to diversify their loan portfolios rather than to transfer risk. Accordingly, we propose the following hypothesis stated in the alternative form:

\section{H1: Banks located in countries with high $R A$ are more likely to be risk averse when engaging in asset securitization activities.}

On a firm-specific level, the relationship between religiosity and organizational behavior is predicated on the social norm theory. Management of a corporation with high religious norms tends not to act in a manner that violates a social norm or to face social sanctions (Stavrova et al; 2014; Leventis et al. 2015). A high level of societal trust is expected to support an organization's economic growth and social efficiency (La Porta et al. 1997; Zak and Knack 2001). Similar to people, religious 
organizations are likely to be risk averse (Osoba, 2003; Hilary and $\mathrm{Hu}, 2009$ ).

As mentioned earlier, the conventional asset securitization (originate-to-distribute) model conveys a relaxed structure of asset securitizations, which involves risk taking followed by transfer. Present or future asset claims of varying maturity and quality are converted into tradable debt securities (DeLorenzo, 2007; Totaro, 2009), ${ }^{6}$ with a theoretical aim of diversifying or shifting risk. However, in practice, this model tends to support a false sense of confidence that risks have been fairly assessed, understood, and managed. In contrast, the constrained asset securitization model of RA banks requires specific monitoring mechanisms to ensure an adequate level of risk sharing and asset ownership transfer to the new investors. This involves an originator selling existing or future revenues from lease receivables, profit-sharing contracts, or private equity from a portfolio of acceptable assets to a special purpose vehicle. This entity refinances itself by issuing unsecured securities to market investors (Jobst, 2007). Investors do not hold a conditional or secured payment obligation; a sufficient element of ownership must instead be clarified to investors. This constrained model of securitization is arguably less opaque compared with the conventional model given that existing assets should back up the securitized loans. In addition, RA banks are prohibited from entering into excessive uncertainty activities like derivatives and hedging.

For RA banks, any deceptive activity is expected to be restrained because these banks act in line with their religious norms, which are presumably based on honesty, fairness, and trust. The constrained finance model is expected to operate by sharing risk and incentives among securitization participants in accord with these banks' moral accountability and responsibility for handling risk. Drawing upon both the social norm theory and constrained securitization model for RA banks, we argue that problems of destructive justice in risk transfer are not dominant for these organizations. Managers in banks with high religious orientations are morally responsible for corporate policymaking and selection of investment opportunities, which likely deters a risk-taking and riskshifting attitude. With the restrictions imposed on their securitization model and the extra religious monitoring of RA banks, they are more likely to engage in securitization activities to improve their financial performance and obtain access to market funding sources rather than to transfer credit risk. This expectation leads to the second hypothesis as follows:

H2: Compared with conventional banks, RA banks are more likely to securitize to improve

\footnotetext{
${ }^{6}$ In a typical transaction, the originating bank transfers a pool of financial assets with fixed or nearly fixed cash flows to an special purpose vehicle. This represents a legal entity that in turn finances the purchase through the issuance of securities backed by the pool. These securities must also be grouped in one of the top two ratings as determined by an accredited credit rating agency and usually pay periodic payments that are similar to coupon payments (Bowden and Lorimer, 2009).
} 


\section{performance rather than to shift risk.}

\section{Data and Sample}

Consistent with prior literature, we capture organizational religiosity through bank type to cluster RA banks and conventional banks. We also operationalize religiosity at the geographic level by employing a dominant variable, which is the importance of RA within each geographic area (Boone et al. 2013; Callen and Fang 2015; Chourou 2013; Dyreng et al. 2012; Grullon and Kanatas 2010; Hilary and Hui 2009; Kumar et al. 2011). This variable is a cognitive element of religiosity, which implicitly represents RA and knowledge. We use a comprehensive measure of geographic religiosity by using the responses to the global Gallup Poll research conducted in 2009 for 114 countries that asked participants "Is religion important in your daily life?" The total reported religious adherents' responses across all countries varied between $27 \%$ and $\geq 99 \%$ (Crabtree, 2010). Countries with the highest respondent rates are Bangladesh, Indonesia, and Yemen, and those with the lowest rates are the United Kingdom and Turkey. Results are based on telephone and face-to-face interviews conducted with approximately 1000 adults in each country, with $95 \%$ confidence that the maximum margin of sampling error ranges from \pm 5.3 to \pm 2.6 percentage points.

The key dependent variable in this study is the decision for asset securitization. This variable represents the activity level and is measured as the total securitization for bank $i$ at time $t$ issuance deflated by total assets (Barth et al., 2010; Casu et al., 2013). To identify the effect of securitization on bank performance and risk taking, we define asset securitization activity as banks that engage in asset securitization transaction for at least one observation of securitization and switched from being a nonsecuritizer during one observation year at time $t$.

A substantial portion of our data on securitization was hand-collected. Annual asset securitization data were hand-collected from the annual reports and notes of banks. These reports are from such data sources as Thomson One, Bankscope, and bank websites. The global list of RA banks involved in asset securitization issuances was initially identified using Thomson-Reuters Zawya and IFIS databases. Our objective is to use the specific features of asset securitization in different bank types (RA and conventional banks) to identify the impact of organizational religiosity on banks' decision to securitize. We collected bank-level data from "Bankscope" and the "Banker" databases. Country-level variables and macroeconomic data were collected from the World Bank and IMF websites.

We employ an unbalanced panel data set and a country variable criterion, reflecting countries with at least four banks and at least two observations for each bank, following Beck et al. (2013). Based on this sample identification process, our final sample includes banks operating within 22 countries 
where RA banks are present. ${ }^{7}$ Our sample comprises 672 banks (4889 bank-year observations) including 136 RA banks (865 year-observations) and 536 conventional banks (4024 yearobservations) for the period of 2003-2012. Securitizer banks represents 287 year-observations (82 banks) and nonsecuritizers constitute 4602 year-observations (664 banks). Table 1 reports the sample composition by country and bank type. We find that banks with asset securitization activity represent $12 \%$ of the total global sample composition. For securitizers, the highest concentration is located in the United Kingdom, Turkey, and UAE.

\section{[Insert Table 1 here]}

\section{Empirical Model}

We follow Casu et al. (2013) for employing banks' propensity to securitize and probit regression estimations using a dummy variable that has a unit value for the securitization decision type, and zero otherwise. Two estimation models are generally identified for each category of banks securitizations: securitizers versus never-securitizer. Our estimation model is developed in line with Caliendo and Kopeinig (2008) to separate the propensity estimation from the average treatment of the group:

$$
P\left(S_{i t}=1 \mid X_{i t-1,} Z_{i t-1}, M A C R O_{j}\right)
$$

Where $S_{i t}$ is a set of the securitization decision dummies, $X_{i t-1}$ is a vector of bank-level characteristics, $Z_{i t-1}$ is a vector of the variables capturing the religiosity indicators, and $M A C R O_{j}$ is the country-level macroeconomic variables. Consistent with Casu et al. (2013) and Caliendo and Kopeinig (2008), we predict that the propensity to securitize/nonsecuritize in the current period $t$ is affected by bank-specific and religiosity variables in the prior period; therefore, variables are lagged by 1 year. We control for dependence of standard errors for a given bank by clustering the standard errors at the bank level.

We include several additional measures of endogenous variables as proxies for (a) capital adequacy, (b) credit risk, (c) cost efficiency, (d) profitability, (e) liquidity, and (f) the quality, growth, and composition of loan portfolios. Following Demirgüç-Kunt and Huizinga (2010) and Beck et al. (2013), we employ a bank capital adequacy measure, the capital adequacy ratio (CAR), which is

\footnotetext{
${ }^{7}$ The countries are Algeria, Bangladesh, Brunei, Mauritania, Iraq, Jordon, Kuwait, Bahrain, Egypt Lebanon, Malaysia, Mauritania, Pakistan, Palestine, Qatar, Saudi Arabia, Syria, Tunisia, United Arab Emirates, Turkey, United Kingdom, and Yemen.
} 
calculated as (Tier $1+$ Tier 2)/total risk-weighted assets. CAR reflects the legal regulatory requirements for capitalization and measures the adequacy level and buffers maintained (Fonseca and González, 2010; Buch and Prieto, 2014; Ebrahim et al., 2014). Following prior literature we measure credit risk as nonperforming loans to gross loans ratios (Gonzalezet al., 2005; Lepetit et al., 2008; Abedifar et al., 2013; Beck et al., 2013). ${ }^{8}$ The overheads to total assets ratio is used as to measure cost efficiency (Johnes et al. 2013; Beck et al., 2013). This measure is expected to capture the dynamics of operational efficiency affecting bank performance. Bank profitability is also used to indicate a bank's earning capability through ROAE (Minton et al. 2004; Čihák and Hesse, 2010; Casu et al., 2013). The liquidity indicator reflects a bank's ability to repay short-term obligations. We use the ratio of liquid assets to total deposits and borrowings to measure bank liquidity management (Beck et al., 2013).

We also indirectly measure additional motives for securitization through the loan HerfindahlHirschman Index (HHI) and the total deposits to total assets ratio, which captures the portfolio diversification. Both the operating income to total revenue and the noninterest income to net operating revenue ratios capture the banking activity diversification motive. An increase in the share of noninterest income in total operating income is expected to lower bank financial performance and stability since an increased reliance on noninterest income raises the volatility of bank loan portfolios without a direct link to increased profits (DeYoung and Roland, 2001; Stiroh 2010). Banks with a high share of nonoperating income encounter high insolvency risk (Lepetit et al., 2008). Loan growth is captured through both the total loan to total assets ratio and the loan growth rate (Affinito and Tagliaferri 2010; Casu et al., 2013), and finally, bank size is used to capture the possible influence of economies of scale (Uzun and Webb 2007, Bannier and Hansel 2008). Size accounts for big banks that might have smaller capital buffers and hence are more risky, which according to the "too-big-tofail" hypothesis suggests that large banks will receive regulatory support during financial distress or when they have lower risk because of the enhanced diversification of their asset portfolio (Olson and Zoubi, 2008; Parashar and Venkatesh, 2010; Fonseca and González, 2010; Abedifar et al., 2013; Beck et al., 2013). We control for bank age to proxy bank's capability and use informational advantages to control for risks (DeYoung and Hasan, 1998).

We additionally control for a set of macroeconomic variables, including market power,

\footnotetext{
${ }^{8}$ Nonperforming loans are defined as loans in the bank's portfolio that are overdue by more than 90 days on interest or principal payments. They are disclosed as supplemental financial statement information (Wahlen, 1994).
} 
through a proxy for the market share of deposits, measured as the total bank deposits over the total banking sector deposits (Berger, 1995; Hasan et al., 2013). We also control for the country's prevailing inflation rate, and we control for the growth in the prosperity of the population by including the growth in GDP per capita (Fang et al. 2014; Mili et al. 2014). According to Demirgüç-Kunt and Detragiache (1998), bank crises are more prevalent in countries with low GDP growth and high inflation and real interest rates. In periods of high economic growth, demands on loans and financial services provided by both RA banks and conventional banks are likely to increase. This situation is expected to increase bank cash flow, interest earnings, and profits. Since our study period falls within the crisis, we predict the growth variable, GDP, to be a negative determinant of bank performance (Subramanian et al., 2013). Regarding the inflation variable, in conventional banking high inflation rates should lead to higher loan rates, which in turn would lead to higher revenues (Bashir, 2000; Haron, 2004). For RA banks, inflation is likely to be positively associated with performance only if a large portion of profits accrue from debtbased contracts (i.e., Murabaha) (Subramanian et al., 2013). In our study, with the assumption that religiously adhered banking is currently mostly based on debt rather than equity-based contracts, we expect inflation to have a positive effect on RA banks' performance. In addition, because RA banks are prohibited from charging fixed interest rates, profitability is likely to be positively associated with the domestic inflation rate. Table 2 presents the variable definitions for our model.

\section{[Insert Table 2 here]}

\section{Descriptive Statistics}

For our pooled sample, a securitizer bank constitutes $60 \%$ of total assets of the pooled sample and $6 \%$ of the total market share for banks' deposits (MSD). These results are consistent with previous research that finds that larger banks are more likely to securitize than small ones (Minton, Sanders, and Strahan 2004, Uzun and Webb 2007, Bannier and Hänsel 2008, Jiangli and Pritsker 2008, Minton, Stulz, and Williamson 2009).

Table 3 presents the descriptive statistics of our data. We report comparative descriptive statistics for securitizers in Panel A and nonsecuritizers in Panel B.

Comparisons across the two subsamples show that securitizers are older with a mean age of 45 (35); however, they have low capital adequacy with a CAR average ratio $22 \%$ (23\%), have high 
credit risk with an average NPL/GR ratio of $10 \%(8.4 \%)$, are less cost efficient with an average ratio of OVtoTA of $41 \%$ (30\%), have poorer diversifications of loan portfolio with a Loam HHI mean of $0.14(0.16)$, and slow loan growth mean of $18 \%$ (22\%), respectively, than banks that were never involved in asset securitization in our total sample. These results provide primary insights into the underlying motives for engagement in asset securitization activities, and they are in line with prior literature (see Haensel and Krahnen, 2007; Mian and Sufi, 2009; Affinito and Tagliaferri, 2010; Casu et al., 2013).

\section{[Insert Table 3 here]}

Table 4 presents the Pearson correlation coefficients. Correlations among independent variables are within accepted limits and raise no concerns with respect to multicollinearity.

\section{[Insert Table 4 here]}

\section{Empirical Results}

Prior studies attempt to identify underlying motives and reasons for banks' securitization and the impact on banks' risk profile, this study is the first to examine the role of geographic and organizational religiosity on banks' propensity to securitize.

\section{6.a Impact of Religiosity on Securitization}

We examine the impact of both geographic religiosity (GR) and organizational religiosity (OR) on asset securitization for the full sample. We explore different motives of asset securitization activity including (i) achieving higher capital adequacy (CAR); (ii) shifting credit risk (NPL/GR); (iii) improving cost efficiency (OVtoTA); and (iv) promoting higher quality loan portfolio and diversifications (INCO, Loan HHI, Loan growth). Our results in Table 5 show that banks located in countries with high GR are less likely to securitize, indicating a risk-averse behavior. These findings are in line with Leventis et al. (2015), Kanagaretnam et al. (2015), Dyreng et al. (2012), and McGuire et al. (2012), which suggest that lower risk taking occurs in countries characterized by high RA. However, banks with organizational religiosity (OR) are more likely to embark on asset securitization activity utilizing their constrained model of securitization, which does not compromise their ethical constraints.

The financial motives for the full sample indicate that banks tend to use securitization to improve their cost efficiency (high OVtoTA ratio), diversify their loan portfolios (low loan HHI), and promote better loan growth (low loan growth ratio). These results are consistent with Jones (2000) who suggests that banks securitize to 
take advantage of increased economies of scale, to reduce the costs of debt financing, and to diversify funding sources. Results are also consistent with Casu et al. (2013) who indicate that banks are likely to securitize to reduce their funding costs, improve liquidity, and diversify funding structure. Controlling for the impact of the financial crisis (2007-2008) shows no significant effect on banks' decisions to securitize. For further insights beyond the pooled sample, we conduct additional analyses to examine the monitoring role of religiosity in risk shifting within highly religious geographic locations and organizations.

\section{[Insert Table 5 here]}

\section{6.b Testing the Impact of Geographic Religiosity (Within Subsample Test)}

We cluster our sample into high and low geographic religiosity (GR). The results for the clustered analysis are in Table 6. We find that banks located in countries with high geographical religiosity (GR) and banks that embark on securitization activity show low credit risk (NPLtoGR), low loan concentration (Loan HHI), and low loan growth (Loan Growth) in the prior year. These results indicate that securitized banks in countries with high RA do not securitize to shift credit risk. Instead, these banks use securitization to improve their loan portfolio diversification and growth in the prior period. These results conform to predictions and are consistent with Casu et al. (2013) that banks are likely to enter the activity when they can take advantage of their strong credit profile and access benefits from reducing the funding costs/operating on higher economies of scales.

Banks located in countries with low GR show significantly high cost efficiency (low OVtoTA) and high operating income (high INCO) but high credit risk (high NPLtoGR) in the prior year. These findings indicate that these banks ultimately use asset securitization more frequently to shift their credit risk. These results support existing studies (e.g., Mian and Sufi, 2009; Keys et al., 2010; and Dell'Ariccia et al., 2012) that suggest that U.S. banks securitized their worst mortgage loans during the last decade. Results in this section conform to the first hypothesis predicting risk-averse behavior for banks located in high geographic religiosity areas.

\section{[Insert Table 6 here]}

\section{6.c Testing the Impact of Organizational Religiosity (Within Subsample Test)}


We further cluster our sample into RA banks (RAs) and conventional banks (CBs). The results are reported in Table 7. Our results show that RA banks have low capital adequacy (low CAR), low credit risk (low NPL/GR), low loan growth ratio, and high operating income (high INCO) in the prior year. These findings indicate that RA banks do not use asset securitization to shift risk. Instead, these banks seem to use securitizations to obtain access to external funding and to enhance their liquidity buffers (Casu et al. 2013; Affinito and Tagliaferri, 2010), which is challenging under their constrained securitization model. Our results confirm prior findings by Minton et al. (2004) that suggest access to market funding through asset securitization creates a greater opportunity to diversify lending portfolios. Given RAs' constrained securitization model, our results suggest that both financial and regulatory challenges, but not risk shifting, motivate RAs to engage in asset securitization. The moral constraints in RA banks appear to restrain transfer of credit risk to third parties, showing careful attention to the banks' underlying incentives to use securitizations.

Conversely, the results for the conventional banks $(\mathrm{CBs})$ subsample show that these banks ultimately use securitizations to transfer credit risk (high NPLtoGR), with additional economic benefits being the diversifications of their sources of funds (low Loan HHI in prior year). Our results show that CBs exhibit high cost efficiency (low OVtoTA) and high operating income (high INCO) in the prior year, which indicates that risk shifting is the ultimate motive for asset securitization decisions in these banks. These findings are in line with prior literature for $\mathrm{CBs}$ that indicates substantial use of securitizations to pass on credit risk to new investors (Dell'Ariccia et al. 2009; Mian and Sufi 2009; and Keys et al. 2010).

\section{[Insert Table 7 here]}

Taken together, our findings indicate a significant impact of the two religiosity indicators on banks' decisions for asset securitization. The results show that the main motive is to improve their financial performance rather than to shift risk, which is an ethically questionable motivation.

For our international sample of banks, geographic areas with high RA are less involved in this high-risk activity (securitizations) and only engage in it to promote better financial and operating performance. Banks located in countries with less RA show a poor credit profile in the year before embarking on securitization, which suggests that credit risk shifting is their main motive. Results for RA banks are in line with the social norms theory. These banks do not intend to use asset securitizations to transfer credit risk, which is ethically impermissible under their orientations. Findings for conventional banks also confirm the arguments for the use of asset securitizations 
Originate-to-Distribute model to shift high credit risk to new investors (Dionne and Harchaoui, 2003; Cebenoyan and Strahan, 2004; Mian and Sufi, 2009; Keys et al., 2010; Purnanandam, 2011; Casu et al., 2011). This motive raises many ethical concerns about this model and questions about how it should be monitored and regulated in the future. Overall findings highlight the importance of identifying the impact of religiosity and ethics in assessing the prevalent conventional securitization models and generally in global banking studies.

\section{6.d Robustness Checks}

In developing the main tests on the relation between religiosity and bank risk, we base our rationale on previous researchers who demonstrate that religiosity is associated with risk aversion. To test whether this relationship holds in our sample, we control for additional measures, such as country governance and ownership structure. The country governance variables are represented by the

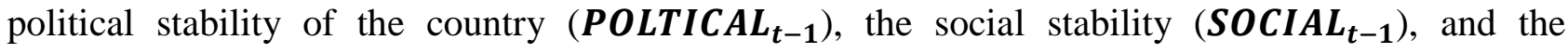
regulatory quality $\left(\boldsymbol{R} \boldsymbol{Q}_{t-1}\right)$. The ownership types include the following categories: financial institution, corporate, private, government, and foreign (Iannotta et al., 2007; Pennathur et al. 2012).

In Table 8, Model 1, we control for the country governance variable. Our results show that geographic religiosity does indeed have a significantly negative coefficient in relation to banks' decision to securitize. Countries with a high RA variable are negatively associated with banks' propensity to securitize. The organizational religiosity variable has a consistently positive and significant coefficient, suggesting that RA banks are more likely to embark on asset securitization activity utilizing their constrained model of securitization. This additional testing confirms the robustness of our results for the impact of religiosity on this high-risk activity.

In Table 8, Model 2, we control for the various ownership types. Our results show the robustness of the main findings, which consistently confirm the impact of both religiosity indicators on banks' decisions to securitize. Results also indicate that banks with government ownership (GOV_OWN) are less likely to enter into securitization activity, which tends to be justified by the substantial risk inherent in this activity.

\section{[Insert Table 8 here}

\section{Conclusion}

This study examines the role of religiosity and ethics in mitigating excessive risk-shifting behavior incorporated into a bank asset securitization model. We employ propensity score, using 
probit estimation for a unique data set on asset securitization of 672 commercial banks (4889 yearobservations) in 22 countries (from 2003 to 2012) with a dual banking system (conventional and religious). The theoretical predictions are that securitizing banks with high RA are less likely to engage in securitization to shift risk to new investors. Moreover, banks with high religious orientations more likely to securitize, but they are motivated by improving funding challenges rather than transferring risk.

Our results provide evidence on how religiosity represents a substantial monitoring mechanism that shapes banks' risk-shifting choices. Findings show that both geographic areas and organizational religiosity significantly influence banks' decisions to securitize.

Banks located in countries with high RA are less likely to securitize than those in countries with low RA. Banks located in high RA countries appear to be more risk averse, and they likely enter into securitization to improve loan growth and diversifications rather than to shift credit risk. In contrast, banks located in countries with low RA show significant evidence for using asset securitizations to transfer high credit risk.

Banks with high RA show a responsibility for handling their credit risk. These banks engage in a constrained model of securitizations mainly to gain access to market sources, to enhance their liquidity positions, and to improve their capital adequacy requirements. Results also show that conventional banks are more likely to engage in asset securitization activity to transfer credit risk as well as to improve the quality of their loan portfolio. These results suggest that the conventional securitization model underestimates the potential role of religiosity in monitoring bank risk and stresses a risk-shifting rather than a risk-sharing motive to use asset securitization. Although the conventional securitization model may successfully shield bank funds by transferring assets with the worst credit profile, we argue that this model has jeopardized moral values and ethical terms by deceiving third parties who take on risk and most probably are not in a position to fully assess it. Therefore, the overall results raise important questions about the ethical reasoning underlying banks' growing securitization activities over the past decade. Our results are consistent and robust to additional controls for country governance and bank ownership types.

This study makes several contributions to the field. First, the findings draw upon recent evidence on how religiosity represents an institutional mechanism to enhance banks financial performance and mitigate risk-shifting behavior (Dyreng et al. 2012; McGuire et al. 2012; Leventis et al., 2015; Kanagaretnam et al., 2015). Prior literature on asset securitization has focused on financial motives and economic benefits of using securitization (see for instance Bannier and Hänsel, 2008; Panetta 
and Pozzolo, 2010; Affinito and Tagliaferri, 2010; Purnanandam, 2011), but we show that banks' decisions to engage in securitization activities in order to transfer risk could be significantly tempered by the presence of RA at both the country and the organizational levels. Our study thus offers deeper insights on the determinants of asset securitization decisions. Secondly, we demonstrate that banks within religious contexts operate on the basis of a risk-averse attitude and are more conservative, which could lead to less corporate risk-taking behavior. Therefore, we extend the recently established stream of global banking literature on the importance of religiosity in mitigating banks' risk taking as well as organizations' agency costs (Hilary and Hui 2009; Callen and Fang 2015). Thirdly, we provide evidence on the relative differences in the risk-shifting behaviors between RA banks, whose model of asset securitizations incorporates additional monitoring, and conventional banks' model of securitization. This evidence contributes to a better understanding of the global banking system.

Our findings have important implications for international regulators, policy makers, auditors, shareholders, and managers. We report global evidence of the impact of RA on risk shifting for asset securitization decisions and its implications for agency costs. Although securitization has been perceived as a facilitator of credit growth and loan packaging, restoring public confidence in the due diligence underlying it should start with investigating other nonfinancial determinants of securitization decisions like ethics and religiosity. Therefore, findings in this study provide policy implications that could support current regulatory attempts to boost global institutional reforms within the asset securitization industry. The substitutive role of religiosity appears to be an important element to consider in regulating securitization trading markets and setting financial reporting policies. We raise a call for this ethical factor to be incorporated in the conventional securitization model because of the increasing complexity of securitization transactions and the lack of transparency in the asset market, which is possibly exacerbated by lenient banking regulation. Moreover, regulators and market participants will benefit from our presented empirical evidence that RA banks are assumed to have lower agency costs and are less involved in financial irregularities/risk given their assumed ethical commitments. Findings in this study present extended guidance to researchers and investors in the international banking industry and new perspectives to consider in their investment strategies in asset securitization. These new insights contribute to an ongoing debate about the need to reconsider the role of regulations in monitoring risky activities in the global banking industry.

We note, however, that within the scope of this study, we can only explain why banks are involved in asset securitization. We cannot determine the implications for banks' risk profile and long-term financial stability. We also acknowledge that our research design has certain limitations because 
studying geographic and organizational religiosities does not directly capture the individual religiosity of managers. Our measures are indicative of individual beliefs rather than an assessment of the RA of corporate managers and firms. In addition, while our country-level analyses provide valuable findings on the securitization behavior of banks in 22 countries, the impact of religiosity on securitization might be heterogeneous across different countries because of differences in accounting standards, regulatory practices, or both. Therefore, future research studies need to assess the impact of religiosity within homogenous contexts. Such research could potentially contribute to the continuing debate about the importance of controlling for religion in the context of securitization activities across international capital markets.

We therefore believe that it is important to more actively interact social norms theory with international banking studies. 


\section{References:}

Abedifar, P., Molyneux, P., \& Tarazi, A. (2013). Risk in Islamic banking. Review of Finance 17, 2035-2096.

Acemoglu, Daron, Simon Johnson and James A. Robinson (2005). Institutions as the Fundamental Cause of Long-Run Growth, in: Philippe Aghion and Steven N. Durlauf (eds.), Handbook of Economic Growth. Volume 1A. Amsterdam: Elsevier.

Affinito, M., \& Tagliaferri E. (2010). Why do (or did?) banks securitize their loans? Evidence from Italy. Bank of Italy Discussion Paper No. 741.

Barnett, T., Bass, K., \& Brown, G. (1996). Religiosity, ethical ideology, and intentions to report a peer's wrongdoing. Journal of Business Ethics, 15(11), 1161-1174.

Barth, M. E., Ormazabal, G., \& Taylor, D. J. (2011). Asset securitizations and credit risk. The Accounting Review, 87(2), 423-448.

Bashir, A. H. M. (1999). Risk and profitability measures in Islamic banks: The case of two Sudanese Banks, Islamic Economic Studies, 6 (2), 1-24.

Beck, T. Demirgüç-Kunt, A. \& Merrouche, O. (2013). Islamic vs. conventional banking: Business model, efficiency and stability, Journal of Banking and Finance, 37(2), 433-447.

Belal, A.R., Abdelsalam, O., Nizamee, S.S., 2015. Ethical reporting in Islamic bank Bangladesh limited (1983-2010). J. Bus. Ethics, 129, 769-784.

Boone, J. P., Khurana, I. K., \& Raman, K. K. (2013). Religiosity and tax avoidance. Journal of the American Taxation Association, 35(1), 53-84.

Buch, C. M., \& Prieto, E. (2014). Do Better Capitalized Banks Lend Less? Long-Run Panel Evidence from Germany, International Finance, 17(1), 1-23.

Buchanan, B. G. (2015). Securitization: A Financing Vehicle for All Seasons?. Journal of Business Ethics, 1-19.

Caliendo, Marco, and Sabine Kopeinig. (2008). Some Practical Guidance for the Implementation of Propensity Score Matching. Journal of Economic Surveys, 22, 31-72.

Callen, J. and Fang, X. (2015). Religion and stock price crash risk. Journal of Financial and Quantitative Analysis.

Callen, J., Fang, X., 2013. Religion and stock price crash risk. Journal of Financial and Quantitative Analysis, forthcoming.

Cantor, R. M., \& Rouyer, S. (2000). Another perspective on risk transference and securitization. Journal of Risk Finance, 1(2), 37-47.

Casu, B. Clare, A. Sarkisyan, A., and Thomas, S. (2011). Does securitization reduce credit risk taking? Empirical evidence from US bank holding companies. The European Journal of Finance, 17, 769-788.

Cebenoyan, S.A, \& P.E. Strahan. (2004). Risk management, capital structure and lending at banks. Journal of Banking and Finance, 28 (1), 19-43.

Čihák, M., \& Hesse, H. (2010). Islamic banks and financial stability: An empirical analysis. Journal of Financial Services Research 38, 95-113.

Crabtree, S. 2010. Religiosity Highest in World's Poorest Nations. Gallup. Retrieved 20 May 2013. http://www.gallup.com/poll/142727/religiosity-highest-world-poorest-nations.aspx

Dell'Ariccia, G. Igan D., \& Laeven, L.A. (2009). Credit booms and lending standards: Evidence from the subprime mortgage market. European Banking Center Discussion Paper No. 2009-14S. 
Demirgüç-Kunt, A., \& Huizinga, H. (2004). Market discipline and deposit insurance. Journal of Monetary Economics, 51(2), 375-399.

DeYoung, R., \& Hasan, I. (1998). The performance of de novo commercial banks: A profit efficiency approach. Journal of Banking \& Finance, 22(5), 565-587.

DeYoung, R., \& Roland, K. P. (2001). Product mix and earnings volatility at commercial banks: Evidence from a degree of total leverage model. Journal of Financial Intermediation, 10(1), 5484.

Dionne, G., \& Harchaoui, T.M. (2003). Banks' capital, securitization and credit risk: An empirical evidence for Canada. HEC Working Paper No. 03-01.

Donaldson, T. (2012). Three ethical roots of the economic crisis. Journal of Business Ethics, 106, 5-8.

Davidson, A., \& Securitization, S. (2003). Investment analysis.

Downing, Christopher, Dwight Jaffee, and NancyWallace, 2009, Is the market for mortgage-backed securities a market for lemons? Review of Financial Studies 22, 2457-2494.

Dyreng, S., Mayew, W. J., Williams, C. D., 2012. Religious social norms and corporate financial reporting. Journal of Business Finance and Accounting 39 (7-8), 845-875.

Ebrahim, M.; Girma, S., Shah, M., \& Williams, J. (2014). Dynamic capital structure and political patronage: The case of Malaysia, International Review of Financial Analysis, 31, 117-128.

Longenecker, J. G., McKinney, J. A., \& Moore, C. W. (2004). Religious intensity, evangelical Christianity, and business ethics: An empirical study.Journal of business ethics, 55(4), 371-384.

Fang, Y. Hasan, I., \& Marton, K. (2014). Institutional development and bank stability: Evidence from transition countries, Journal of Banking \& Finance, 39, 160-176.

Fonseca, A. R., \& González, F. (2010). How bank capital buffers vary across countries: The influence of cost of deposits, market power and bank regulation. Journal of banking \& finance, 34(4), 892-902.

Franke, G., \& Krahnen, J.P. (2005). Default risk sharing between banks and markets: The contribution of collateralized debt obligations. CFS Working Paper No. 2005/06.

Gorton, G., \& Metrick, A. (2012) Securitization, NBER working paper No. 18611.

Gorton, G. (2012). Misunderstanding financial crises: Why we don't see them coming. Oxford: Oxford University Press.

Grullon, G., Kanatas, G. and Weston J. (2010). Religion and corporate (mis)behavior. Working Paper, Rice University.

Ha-Brookshire, J., 2015. Toward moral responsibility theories of corporate sustainability and sustainable supply chain. J. Business. Ethics. doi:10.1007/s10551-015-2847-2.

Haensel and Krahnen, 2007. Does Credit Securitization Reduce Bank Risk? Evidence from the European CDO Market. BBS working paper 14-006.

Hänsel, Dennis N., and Christina E. Bannier. (2008) 'Determinants of European Banks' Engagement in Loan Securitization.” Discussion Paper Series 2: Banking and Financial Studies, 2008,10, Deutsche Bundesbank, Research Centre.

Haron, S. (2004). Determinants of Islamic banks profitability, Global Journal of Finance and Economics, 1 (10), 49-64.

Hess, A. C., and Clifford W. S. (1988) "Elements of Mortgage Securitization.” Journal of Real Estate Finance and Economics, 1, 331-46.

Hilary, G., \& Hui, K. W. (2009). Does religion matter in corporate decision making in America?. Journal of Financial Economics, 93(3), 455-473.

Innaccone, L. (1998). Introduction to the economics of religion. Journal of Economic Literature, 36(3), 1465-1496 
Jobst, A. (2007). The economics of Islamic finance and securitization. IMF Working Paper. International Monetary Fund.

Johnes, J. Izzeldin, M. \& Pappas, V. (2013). A comparison of performance of Islamic and conventional banks 2004 to 2009, Journal of Economic Behavior \& Organization, Accepted Manuscript.

Jones, David. (2000) "Emerging Problems with the Basel Capital Accord: Regulatory Capital Arbitrage and Related Issues." Journal of Banking and Finance, 24, 35-58. Journal of Financial Economics 105, 332-352.

Kanagaretnam, K., Lobo, G. J., \& Wang, C. (2015). Religiosity and Earnings Management: International Evidence from the Banking Industry. Journal of Business Ethics, 132(2), 277-296.

Kaptein, M. (2011). Toward effective codes: Testing the relationship with unethical behavior. Journal of Business Ethics, 99(2), 233-251.

Kennedy, E. J., \& Lawton, L. (1998). Religiousness and business ethics. Journal of Business Ethics, 17(2), 163-175.

Keys, B. J.,Tanmoy M., Amit Seru, and Vikrant Vig.(2010) Did Securitization Lead to Lax Screening? Evidence from Subprime Loans." Quarterly Journal of Economics, 125, 307-62.

Kiff, J., \& Kisser, M. (2014). A shot at regulating securitization. Journal of Financial Stability, 10, 32-49.

Kumar, A., Page, J., \& Spalt, O. (2011). Religious beliefs, gambling attitudes and financial market outcomes. Journal of Financial Economics, 102(3), 671-708.

La Porta, R. Lopez-de-Silanes, F. Shleifer, A. Vishny, R. (1997). Legal determinants of external finance, Journal of Finance 52, 1131-1150.

Lepetit, L.; Nys, E.; Rous, P., \& Tarazi, A. (2008). Bank income structure and risk: An empirical analysis of European banks. Journal of Banking \& Finance, 32 (8), 1452-1467.

Leventis, S., Dedoulis, E., \& Abdelsalam, O. 2015. The Impact of Religiosity on Audit Pricing. Journal of Business Ethics, 1-26

Longenecker, J. G., McKinney, J. A., Moore, C. W., 2004. Religious Intensity,

Loutskina, Elena, and Philip Strahan, 2009, Securitization and the declining impact of bank finance on loan supply: Evidence from mortgage originations, Journal of Finance 64, 861-889.

Mazar, N., Amir, O., \& Ariely, D. (2008). The dishonesty of honest people: A theory of self-concept maintenance. Journal of Marketing Research, 45(6), 633-644.

McCullough, M. E., Willoughby, B.L.B., 2009. Religion, Self-Regulation and Self-Control: Association, Explanation and Implications. Psychological Bulletin 135, 69- 93.

McGuire, S., Omer, T. C., Sharp, N. Y., 2012. The impact of religion on financial reporting irregularities. The Accounting Review 87, 645-73.

McConnell, J. J., \& Buser, S. A. (2011). The origins and evolution of the market for mortgagebacked securities. Annual Review of Financial Economics, 3.

Mian, A.R., \& Sufi, A. (2009). The consequences of mortgage credit expansion: Evidence from the 2007 mortgage default crisis. NBER Working Paper No. W13936.

Mili, M. Sahut, J. M., \& Trimeche, H. (2014). Determinants of the Capital Adequacy Ratio of a Foreign Bank's Subsidiaries: The Role of the Interbank Market and Regulation of Multinational Banks, IPAG Working Paper, (No. 2014-366).

Miller, A., \& Hoffmann, J. (1995). Risk and religion: An explanation of gender differences in religiosity. Journal for the Scientific Study of Religion, 34(1), 63-75.

Minton, B. A., Anthony Sanders, and Philip E. Strahan. (2004) "Securitization by Banks and Finance Companies: Efficient Financial Contracting or Regulatory Arbitrage?" Charles A. Dice Center for Research in Financial Economics Working Paper No. 2004-25 
Minton, B. A., Stulz, R., \& Williamson, R. (2009). How much do banks use credit derivatives to hedge loans?. Journal of Financial Services Research,35(1), 1-31.

Olson, D. \& Zoubi, A. (2008). Using accounting ratios to distinguish between Islamic and conventional banks in the GCC region, The International Journal of Accounting, 43 (1), 45-65.

Osoba, B. (2003). Risk preferences and the practice of religion: evidence from panel data. Working Paper, West Virginia University.

Panetta, Fabio, and Alberto F. Pozzolo. (2010) "Why Do Banks Transfer Credit Risk? Bank-Level Evidence from over One Hundred Countries.” Manuscript. DOI:10.2139/ssrn.1572983.

Parashar, S.P. \& Venkatesh, J. (2010). How did Islamic banks do during global financial crisis, Banks and Bank Systems, 5 (4), 54-62.

Pavel, C. A., \& Phillis, D. (1987). Why commercial banks sell loans: An empirical analysis. Economic Perspectives, (May), 3-14.

Purnanandam, A.K. (2009). Originate-to-distribute model and the sub-prime mortgage crisis. AFA 2010 Atlanta Meetings Paper.

Rosenthal, James A., and Juan M. Ocampo. (1988) Securitization of Credit: Inside the New Technology of Finance. New York: John Wiley \& Sons.

Shukor, A., \& Jamal, A. (2013). Developing scales for measuring religiosity in the context of consumer research. Middle-East Journal of Scientific Research, 13, 69-74.

Smith, A. (1976). Theory of moral sentiments. Indianapolis: Liberty Classics.

Stiroh, K. J. (2010). Diversification in banking, in Oxford Handbook of Banking (Eds) A. N. Berger, P. Molyneux and J. O. S. W Subramanian, U.,Wahidudin, A., \& Kamaluddin, P. (2013). Determinants of Profitability-A Comparative Analysis of Islamic Banks and Conventional Banks in ASEAN Countries, Working paper. Mutalib Pg., Determinants of Profitability-A Comparative Analysis of Islamic Banks and Conventional Banks in ASEAN Countries (April 16, 2013).

Stulz, R., and Williamson, R. 2003. Culture, openness, and finance. Journal of Financial Economics, 70, 313-349.

Subramanian, U., Wahidudin, A., \& Kamaluddin, P. (2013). Determinants of Profitability-A Comparative Analysis of Islamic Banks and Conventional Banks in ASEAN Countries (April 16, 2013), mimeo.

Totaro, L. (2009). Vatican Says Islamic Finance May Help Western Banks in Crisis, Rome: Bloomberg.

Uzun, H., and Webb, E. (2007). Securitization and Risk: Empirical Evidence on US Banks. The Journal of Risk Finance 8, 11-23.

Vitell, S. J. 2009. The Role of religiosity in business and consumer ethics: A review of the literature. Journal of Business Ethics, 90, 155-167.

Weaver, G. R., Agle, B. R., 2002. Religiosity and Ethical Behavior in Organizations: A Symbolic Interactionist Perspective. Academy of Management Review 27, 77-97.

Weber, M. (1905). The protestant ethic and the spirit of capitalism. London: Allen \& Unwin.

Zak, P. J., \& Knack, S. (2001). Trust and growth. The economic journal,111(470), 295-321. 
Table 2 Definition and Descriptions for the Test Variables

$\begin{array}{lll}\text { Variables Notations } & \text { Definitions }\end{array}$

\section{Dependent Variables:}

\section{Securitizers}

Non-securitizers

\section{Independent Variables:}

\subsection{Religiosity:}

b. Geographical Religiosity

d. Organizational Religiosity

2.2 Bank Characteristics:

a. Capital capitalization

\section{b. Credit Risk}

c. Cost Efficiency

d. Loan Herfindahl-Hirschman Index (HHI)
SEC

Non_SEC

A dummy indicator equal 1 for banks that engage in asset securitization transaction with at least one observation of asset securitization and switched from being non-securitizer during one observation year at time $t$ and 0 otherwise.

A dummy indicator equal 1 for banks that do not undertake any securitization activity throughout the sample observation period and 0 otherwise.

An indicator for the percentage of people positive response to the question "Is religion important in your daily life?" according to global Gallup Poll research conducted. Data as of 2014. This variable is divided into:

(i) High importance: equal 1 if the citizens of the country responses are (positive) above or equal to the average (0.87575) of 22 counties in the sample, 0 otherwise.

(ii) Low importance: equal 1 if the citizens of the country responses are (negative) above or equal to the average (0.1135) of 22 counties in the sample, 0 otherwise.

Dummy variable equal 1 for banks with religious adherence and 0 for Conventional banks.

$\mathbf{O R}_{\mathbf{i}}$

$$
\boldsymbol{C A R}_{\boldsymbol{i t}-\mathbf{1}}(\%) \quad \text { Capital Adequacy Ratio }
$$

NPLtoG $\boldsymbol{R}_{i t-1}(\%) \quad$ Non-Performing Loans to Gross Loans ratio

OVtoTA $_{\text {it-1 }}(\%) \quad$ Overheads to Total Assets ratio

Loan $\mathbf{H H I}_{i t-\mathbf{1}} \quad$ Herfindahl-Hirschman Index for total loans 
e. Loan growth rate

f. Operating income ratio

2.3 Other Bank Controls
a. Profitability
b. Liquidity
d. Deposit ratio
e. Noninterest income ratio
f. Loan ratio
g. Bank size
h. Bank Age

\subsection{Country Governance:}

a. Political Stability

b. Social Stability

c. Regulatory Quality

\subsection{Ownership Type:}

a. Financial Ownership

b. Corporate Ownership

c. Private Ownership

d. Government Ownership

e. Foreign Ownership
Loan Growth it-1 $_{\mathbf{1}}(\%) \quad$ Percentage of change in the total outstanding loans between year $\mathrm{t}$ and yeat $\mathrm{t}-1$

$$
\mathbf{I N C O}_{i t-\mathbf{1}}(\%) \quad \text { Operating income to total revenue ratio }
$$

$\mathbf{R O A E}_{\mathbf{i t}-\mathbf{1}}(\%) \quad$ Return on average equity ratio

LAtoTD $_{\mathrm{it-1}}(\boldsymbol{\%}) \quad$ Liquid Assets to Total deposits and borrowings

$\mathbf{D E P O}_{i t-\mathbf{1}}(\%) \quad$ Total deposits to total assets ratio

NONINT $_{i t-1}(\%) \quad$ Noninterest income to net operating revenue ratio

Loan ratio it-1 $_{(\%)}$ Total loan to total assets ratio

Size $_{i, t-1} \quad$ Natural logarithm of the total bank assets

$\mathrm{AGE}_{\mathrm{i}, \mathrm{t}-1}$

Age of bank since the year of its establishment
Political $_{\mathbf{j}, \mathbf{t}-1}$

Social $_{\mathbf{j}, \mathrm{t}-1}$

$\mathbf{R} \mathbf{Q}_{\mathrm{j}, \mathrm{t}-\mathbf{1}}$
Political Stability and Absence of Violence/Terrorism captures perceptions of the likelihood that the government will be destabilized or overthrown by unconstitutional or violent means, including politically-motivated violence and terrorism.

Social stability refers to the stability of regulation with the restrictions placed on the practice, profession, or selection of religion by other religious groups or associations or the culture at large.

Perceptions of the ability of the government to formulate and implement sound policies and regulations that permit and promote private sector development.

\footnotetext{
$\boldsymbol{F I N A N C I A L}_{\boldsymbol{t}-\mathbf{1}} \quad$ Shareholder from Financial Institutions

CORPORTE $E_{t-1}$ Shareholder from Companies (ORBIS)

$\boldsymbol{P R I V A T E}_{t-1}$ Shares holded from Private shareholders (ORBIS)

GOV_OWN $\boldsymbol{N}_{t-1} \quad 1$ if government ownership is greater than $50 \% 0$ otherwise

$\boldsymbol{F O R} \boldsymbol{O} \boldsymbol{W} \boldsymbol{N}_{\boldsymbol{t}-\mathbf{1}} \quad 1$ if foreign ownership greater than $50 \% 0$ otherwise
} 
2.6 Macroeconomic:

a. Deposit Market concentration

b. GDP growth rate

c. Inflation rate

d. Crisis
A set of country level macroeconomic variables for bank $\mathrm{i}$ in country $\mathrm{j}$ at time $\mathrm{t}$,

Bank i deposits at time t over total banking sector deposits at time

Growth in GDP per capita in country $\mathrm{j}$ at time $\mathrm{t}$

Country-prevailing inflation rate for bank $\mathrm{i}$ in time $\mathrm{t}$.

$\mathbf{I N F}_{\mathrm{i}, \mathrm{t}}$

Crisis $_{\mathrm{t}}$

Time Dummy equal 1 for the financial periods of 2007-2008 and 0 otherwise

Notes: The table reports the variables definitions and notations. 
Table 3 Descriptive Statistics for the Pooled Sample for the Period 2003-2012

\begin{tabular}{|c|c|c|c|c|c|c|}
\hline & \multicolumn{3}{|c|}{ Panel A: Securitizers } & \multicolumn{3}{|c|}{ Panel B: Non Securitizers } \\
\hline Variables & Mean & Median & St.Dev & Mean & Median & St.Dev \\
\hline$C A R_{t-1}$ & 22.235 & 17.120 & 17.235 & 22.718 & 17.120 & 20.496 \\
\hline NPLtoG $R_{t-1}$ & 10.221 & 4.490 & 16.498 & 8.440 & 4.040 & 12.817 \\
\hline ovtoT $A_{t-1}$ & 41.100 & 20.803 & 49.291 & 30.212 & 20.724 & 605.049 \\
\hline Loan $H H I_{t-1}$ & 0.139 & 0.116 & 0.068 & 0.155 & 0.118 & 0.091 \\
\hline Loan Growth ${ }_{t-1}$ & 18.217 & 11.250 & 47.723 & 22.266 & 11.800 & 58.931 \\
\hline$I_{N C O}$ & 0.033 & 0.011 & 0.504 & 0.025 & 0.012 & 0.291 \\
\hline$R O A E_{t-1}$ & 9.375 & 9.114 & 27.879 & 9.677 & 9.679 & 27.897 \\
\hline LAtoT D $_{t-1}$ & 42.504 & 36.549 & 41.231 & 44.541 & 32.405 & 48.273 \\
\hline Loan ratio $_{t-1}$ & 0.454 & 0.449 & 0.237 & 0.475 & 0.496 & 0.229 \\
\hline $\operatorname{DESPO}_{t-1}$ & 0.628 & 0.711 & 0.258 & 0.639 & 0.715 & 0.244 \\
\hline NONINT $T_{t-1}$ & -5.678 & 0.441 & 292.955 & -11.677 & 0.434 & 777.213 \\
\hline Size $_{t-1}$ & 7.184 & 7.044 & 2.147 & 7.258 & 7.238 & 1.907 \\
\hline$A G E_{t-1}$ & 44.743 & 30.000 & 57.995 & 34.909 & 26.000 & 38.682 \\
\hline$M S D_{t-1}$ & 0.045 & 0.007 & 0.099 & 0.048 & 0.011 & 0.092 \\
\hline$G D P G R_{t-1}$ & 8.189 & 7.185 & 9.933 & 8.522 & 8.168 & 10.827 \\
\hline$l N F_{t-1}$ & 4.881 & 3.632 & 4.640 & 5.625 & 4.491 & 4.887 \\
\hline
\end{tabular}

Notes: The table presents the descriptive statistics for the test variables for the period of 2003-2012 comparing two types of asset securitization decisions securitizers and non-securitizers. The study pooled sample reflects banks operating in 22 cross countries with 4889 bank-year observations (672 banks). 


\section{Table 4 Pearson Correlation Coefficients among the Sample Variables for the Full Sample during the Period of 2002-2013}

\begin{tabular}{|c|c|c|c|c|c|c|c|c|c|c|c|}
\hline Variables & CAR $_{t-1}$ & NPLtoGR $R_{t-1}$ & ovtoT A $_{t-1}$ & $R O A E_{t-1}$ & LAtoTD $_{t-1}$ & Size $_{t-1}$ & $\operatorname{NONINT}_{t-1}$ & Loan ratio $_{t-1}$ & Loan $H H I_{t-1}$ & $\operatorname{DESPO}_{t-1}$ & $\mathrm{INCO}_{\mathrm{t}-}$ \\
\hline$C A R_{t-1}$ & 1 & & & & & & & & & & \\
\hline NPLtoG $R_{t-1}$ & $0.1675 *$ & 1 & & & & & & & & & \\
\hline oVtoTA $A_{t-1}$ & $0.1522 *$ & $0.2103^{*}$ & 1 & & & & & & & & \\
\hline$R O A E_{t-1}$ & $-0.0402 *$ & $-0.1601 *$ & $-0.0541 *$ & 1 & & & & & & & \\
\hline LAtoT D $_{t-1}$ & $0.4631 *$ & $0.2052 *$ & $0.0442 *$ & $-0.0568 *$ & 1 & & & & & & \\
\hline Size $_{t-1}$ & $-0.3459 *$ & $-0.2548 *$ & $-0.0996 *$ & $0.0935^{*}$ & $-0.2188^{*}$ & 1 & & & & & \\
\hline$N O N I N T_{t-1}$ & -0.0038 & $0.1951 *$ & $0.0930^{*}$ & $0.1715^{*}$ & $0.0562 *$ & -0.0244 & 1 & & & & \\
\hline Loan ratio $_{t-1}$ & $-0.2517 *$ & $-0.2778 *$ & -0.0132 & $0.0478 *$ & $-0.4332 *$ & $0.2231 *$ & -0.0147 & 1 & & & \\
\hline Loan $H H I_{t-1}$ & -0.0125 & $0.0394 *$ & -0.0085 & 0.0054 & 0.02 & -0.0228 & -0.0056 & $-0.1094 *$ & 1 & & \\
\hline $\operatorname{DESPO}_{t-1}$ & $-0.3438 *$ & $-0.1042 *$ & $-0.1873 *$ & $0.0922 *$ & $-0.2723^{*}$ & $0.1035^{*}$ & -0.0014 & $0.1742 *$ & 0.0085 & 1 & \\
\hline$I N C O_{t-1}$ & $0.0767 *$ & 0.0155 & 0.0064 & -0.012 & 0.0257 & 0.017 & -0.0033 & 0.022 & -0.0002 & 0.0229 & 1 \\
\hline Loan Growth $_{t-1}$ & $0.0919 *$ & $-0.1656^{*}$ & $-0.0403 *$ & $0.0610^{*}$ & -0.0321 & $-0.0682 *$ & 0.0054 & -0.0249 & 0.0035 & $-0.0545^{*}$ & 0.0139 \\
\hline$A G E_{t-1}$ & $-0.1162 *$ & -0.0374 & -0.0186 & 0.0178 & $-0.0831 *$ & $0.3027 *$ & -0.0024 & 0.0207 & $-0.1017 *$ & $0.0981 *$ & -0.0124 \\
\hline$M S D_{t-1}$ & $-0.1222 *$ & $-0.0464 *$ & $-0.1183 *$ & $0.0771 *$ & $-0.0996^{*}$ & $0.3104 *$ & -0.0123 & 0.0017 & $0.2454 *$ & $0.1386^{*}$ & 0.0051 \\
\hline$G D P G R_{t-1}$ & 0.0156 & $-0.0883 *$ & -0.008 & $0.1103^{*}$ & -0.0117 & $-0.0415^{*}$ & 0.0033 & 0 & $0.1466^{*}$ & $0.0862 *$ & 0.0039 \\
\hline$l N F_{t-1}$ & $-0.0469 *$ & $0.0618^{*}$ & -0.0108 & $0.0493 *$ & $-0.0798 *$ & $-0.0884 *$ & -0.0112 & 0.0167 & $0.0826^{*}$ & $0.1211^{*}$ & 0.0074 \\
\hline$R Q_{t-1}$ & $0.0677 *$ & $-0.0918 *$ & 0.0302 & $-0.0903 *$ & $0.1308^{*}$ & $0.1905^{*}$ & 0.0127 & $-0.0849 *$ & $-0.1423^{*}$ & $-0.2854 *$ & 0.0299 \\
\hline POLTICAL $_{t-1}$ & $0.0355^{*}$ & $-0.1408 *$ & 0.0098 & $-0.0470 *$ & $0.0765 *$ & $0.2065^{*}$ & 0.0072 & $0.0807 *$ & 0.0214 & $-0.2061^{*}$ & 0.0235 \\
\hline$S O C I A L_{t-1}$ & -0.024 & $0.0371 *$ & $-0.0376^{*}$ & $0.1086^{*}$ & $-0.1875^{*}$ & -0.0158 & -0.018 & $0.1790^{*}$ & $0.1751 *$ & $0.2426^{*}$ & -0.0156 \\
\hline$G O V_{-} O W N_{t-1}$ & -0.0121 & 0.0144 & -0.0095 & 0.0021 & -0.0393 & $0.1534 *$ & -0.0087 & 0.009 & $-0.0778 *$ & -0.0102 & 0.0043 \\
\hline$F O R_{-} O W N_{t-1}$ & $0.1462 *$ & -0.0186 & -0.0139 & $-0.0698 *$ & $0.0938 *$ & $-0.1254 *$ & -0.0165 & $-0.0409 *$ & $-0.0797 *$ & $-0.1120^{*}$ & 0.0096 \\
\hline
\end{tabular}




\begin{tabular}{|c|c|c|c|c|c|c|c|c|c|c|}
\hline Variables & Loan Growth ${ }_{t-1}$ & $A G E_{t-1}$ & $M S D_{t-1}$ & $G D P G R_{t-1}$ & $l N F_{t-1}$ & $R Q_{t-1}$ & POLTICAL $_{t-1}$ & $S O C I A L_{t-1}$ & $G O V_{-} O W N_{t-1}$ & $F O R_{-} O W N_{t-1}$ \\
\hline Loan Growth $h_{t-1}$ & 1 & & & & & & & & & \\
\hline$A G E_{t-1}$ & $-0.0732 *$ & 1 & & & & & & & & \\
\hline$M S D_{t-1}$ & -0.0248 & $0.0785^{*}$ & 1 & & & & & & & \\
\hline$G D P G R_{t-1}$ & $0.1012 *$ & $-0.0525^{*}$ & $0.0775^{*}$ & 1 & & & & & & \\
\hline$l N F_{t-1}$ & 0.0302 & $-0.1055^{*}$ & $0.0846^{*}$ & $0.2148^{*}$ & 1 & & & & & \\
\hline$R Q_{t-1}$ & $-0.0742 *$ & $0.2435 *$ & $-0.1781 *$ & $-0.2087 *$ & $-0.4575^{*}$ & 1 & & & & \\
\hline POLTICAL $L_{t-1}$ & -0.028 & $0.1148^{*}$ & 0.0068 & $-0.1594 *$ & $-0.4289 *$ & 0.0768 & 1 & & & \\
\hline SOCIAL $_{t-1}$ & $0.0633^{*}$ & $-0.2483^{*}$ & $0.1676^{*}$ & $0.2350^{*}$ & $0.3500 *$ & -0.0747 & $-0.4983^{*}$ & 1 & & \\
\hline$G O V_{-} O W N_{t-1}$ & -0.0019 & $0.0503^{*}$ & $0.1836^{*}$ & -0.0211 & $0.0424 *$ & $-0.0835^{*}$ & -0.0081 & $0.1160 *$ & 1 & \\
\hline$F O R \_O W N_{t-1}$ & -0.005 & $-0.0938^{*}$ & $-0.1796 *$ & $-0.0411^{*}$ & 0.002 & 0.0189 & $-0.0877 *$ & $0.0358 *$ & -0.0222 & 1 \\
\hline
\end{tabular}

Notes: The table reports Pearson correlation coefficients for the test and control variables for the full sample during period of 2003-2012. * stand for statistical significance at the 5\%, level. 
Table 5-Testing for Religiosity Indicators for the full sample VARIABLES

\begin{tabular}{|c|c|}
\hline $\mathbf{G R}_{j}$ & $\begin{array}{c}-0.734 * * * \\
(0.001)\end{array}$ \\
\hline $\mathbf{O} \mathbf{R}_{\mathbf{i}}$ & $\begin{array}{l}0.376^{*} \\
(0.071)\end{array}$ \\
\hline$C A R_{t-1}$ & $\begin{array}{c}0.004 \\
(0.764)\end{array}$ \\
\hline NPLtoGR $R_{t-1}$ & $\begin{array}{c}-0.086 * * * \\
(0.008)\end{array}$ \\
\hline ovtoT $A_{t-1}$ & $\begin{array}{c}-0.012 * \\
(0.051)\end{array}$ \\
\hline Loan $H H I_{t-1}$ & $\begin{array}{l}-2.545^{*} \\
(0.090)\end{array}$ \\
\hline Loan Growth ${ }_{t-1}$ & $\begin{array}{c}-0.006^{*} \\
(0.066)\end{array}$ \\
\hline$R O A E_{t-1}$ & $\begin{array}{c}-0.002 \\
(0.758)\end{array}$ \\
\hline LAtoT D $_{t-1}$ & $\begin{array}{l}-0.003 \\
(0.644)\end{array}$ \\
\hline Size $_{t-1}$ & $\begin{array}{c}0.013 \\
(0.872)\end{array}$ \\
\hline$I_{N C O}$ & $\begin{array}{c}8.872 \\
(0.147)\end{array}$ \\
\hline Loan ratio $_{t-1}$ & $\begin{array}{c}0.437 \\
(0.494)\end{array}$ \\
\hline $\operatorname{DESPO}_{t-1}$ & $\begin{array}{c}0.658 \\
(0.202)\end{array}$ \\
\hline$N O N I N T_{t-1}$ & $\begin{array}{c}-0.011 \\
(0.792)\end{array}$ \\
\hline$A G E_{t-1}$ & $\begin{array}{c}0.001 \\
(0.418)\end{array}$ \\
\hline Crisis $_{t}$ & $\begin{array}{c}0.090 \\
(0.746)\end{array}$ \\
\hline$M S D_{t-1}$ & $\begin{array}{l}-2.800 \\
(0.289)\end{array}$ \\
\hline$G D P G R_{t-1}$ & $\begin{array}{l}-0.005 \\
(0.355)\end{array}$ \\
\hline$l N F_{t-1}$ & $\begin{array}{l}-0.039 \\
(0.359)\end{array}$ \\
\hline Constant & $\begin{array}{l}-1.059 \\
(0.345)\end{array}$ \\
\hline Industry dummies & YES \\
\hline Year dummies & YES \\
\hline $\mathrm{N}$ & 1238 \\
\hline Log likelihood & -1240.85 \\
\hline Pseudo $R^{2}$ & 0.094 \\
\hline
\end{tabular}


Notes: The table reports the probit regression estimates of banks' propensity to securitize assets for the full sample controlling for geographical and organizational religiosity indicators. All explanatory variables are lagged 1 year. Standard errors of estimated coefficients are clustered at the bank level. $*, * *, * * *$ stand for statistical significance at the $10 \%, 5 \%$, and $1 \%$ levels, respectively. Variables definitions in Table (2). 
Table 6-Within High Geographical Religiosity versus Low Geographical Religiosity

\begin{tabular}{|c|c|c|}
\hline VARIABLES & $\begin{array}{c}\text { (1) } \\
\text { High GR }\end{array}$ & $\begin{array}{c}(2) \\
\text { Low GR }\end{array}$ \\
\hline$\overline{C A R_{t-1}}$ & $\begin{array}{c}0.002 \\
(0.854)\end{array}$ & $\begin{array}{c}-0.000 \\
(0.995)\end{array}$ \\
\hline$N P L t o G R_{t-1}$ & $\begin{array}{c}-0.074 * * \\
(0.045)\end{array}$ & $\begin{array}{c}0.121 * * \\
(0.049)\end{array}$ \\
\hline OVtoTA $_{t-1}$ & $\begin{array}{l}-0.003 \\
(0.747)\end{array}$ & $\begin{array}{c}-0.053 * * \\
(0.026)\end{array}$ \\
\hline $\operatorname{Loan} H H I_{t-1}$ & $\begin{array}{c}-3.736^{* *} \\
(0.015)\end{array}$ & $\begin{array}{c}-33.785 \\
(0.279)\end{array}$ \\
\hline Loan Growth ${ }_{t-1}$ & $\begin{array}{c}-0.009 * * \\
(0.030)\end{array}$ & $\begin{array}{l}-0.003 \\
(0.268)\end{array}$ \\
\hline$R O A E_{t-1}$ & $\begin{array}{c}0.005 \\
(0.709)\end{array}$ & $\begin{array}{l}-0.007 \\
(0.515)\end{array}$ \\
\hline LAtoT D $_{t-1}$ & $\begin{array}{l}-0.000 \\
(0.958)\end{array}$ & $\begin{array}{c}0.002 \\
(0.874)\end{array}$ \\
\hline Size $_{t-1}$ & $\begin{array}{l}-0.080 \\
(0.541)\end{array}$ & $\begin{array}{c}0.013 \\
(0.902)\end{array}$ \\
\hline$I_{N C O}$ & $\begin{array}{c}3.231 \\
(0.695)\end{array}$ & $\begin{array}{c}50.930^{* *} * \\
(0.031)\end{array}$ \\
\hline Loan ratio $_{t-1}$ & $\begin{array}{l}-0.379 \\
(0.679)\end{array}$ & $\begin{array}{c}1.421 \\
(0.166)\end{array}$ \\
\hline $\operatorname{DESPO}_{t-1}$ & $\begin{array}{l}-0.245 \\
(0.707)\end{array}$ & $\begin{array}{l}1.627 * \\
(0.068)\end{array}$ \\
\hline NONINT $_{t-1}$ & $\begin{array}{l}-0.027 \\
(0.486)\end{array}$ & $\begin{array}{c}-0.034 \\
(0.278)\end{array}$ \\
\hline$A G E_{t-1}$ & $\begin{array}{l}-0.007 \\
(0.101)\end{array}$ & $\begin{array}{c}0.002 \\
(0.480)\end{array}$ \\
\hline Crisis $_{t}$ & $\begin{array}{c}0.343 \\
(0.430)\end{array}$ & $\begin{array}{l}-0.027 \\
(0.944)\end{array}$ \\
\hline$M S D_{t-1}$ & $\begin{array}{l}-0.557 \\
(0.825)\end{array}$ & $\begin{array}{l}-5.679 \\
(0.407)\end{array}$ \\
\hline$G D P G R_{t-1}$ & $\begin{array}{c}-0.002 \\
(0.778)\end{array}$ & $\begin{array}{l}-0.011 \\
(0.416)\end{array}$ \\
\hline$l N F_{t-1}$ & $\begin{array}{l}-0.018 \\
(0.725)\end{array}$ & $\begin{array}{l}-0.124 \\
(0.404)\end{array}$ \\
\hline OR & $\begin{array}{c}0.624 * * * \\
(0.002)\end{array}$ & $\begin{array}{l}-0.909 \\
(0.118)\end{array}$ \\
\hline Constant & $\begin{array}{c}0.019 \\
(0.990)\end{array}$ & $\begin{array}{c}2.050 \\
(0.635)\end{array}$ \\
\hline Industry dummies & $\begin{array}{l}\text { YES } \\
34\end{array}$ & YES \\
\hline
\end{tabular}


Year dummies

$\mathrm{N}$

Log likelihood

Pseudo $R^{2}$

Notes: The table reports the probit regression estimates of banks' propensity to

religiosity using high (low) importance for religion during the sample period 2003-2012. All explanatory variables are lagged 1 year.

Standard errors of estimated coefficients are clustered at the bank level. *, **,*** stand for statistical significance at the $10 \%, 5 \%$, and $1 \%$ levels, respectively. Variables definitions in Table (2). 


\section{Table 7-Within Banks with Religious Adherence versus Conventional banks}

\begin{tabular}{|c|c|c|}
\hline VARIABLES & $\begin{array}{c}(\mathbf{1}) \\
\text { RAs }\end{array}$ & $\begin{array}{c}(2) \\
\text { CBs } \\
\end{array}$ \\
\hline \multirow[t]{2}{*}{$C A R_{t-1}$} & $-0.128 * *$ & 0.007 \\
\hline & $(0.032)$ & $(0.577)$ \\
\hline \multirow[t]{2}{*}{ NPLtoG $R_{t-1}$} & $-0.415^{*}$ & $0.060 * *$ \\
\hline & $(0.056)$ & $(0.030)$ \\
\hline \multirow[t]{2}{*}{ OVtoT $A_{t-1}$} & 0.024 & $-0.010 *$ \\
\hline & $(0.230)$ & $(0.058)$ \\
\hline \multirow[t]{2}{*}{$\operatorname{Loan} H H I_{t-1}$} & -1.012 & $-3.141 * *$ \\
\hline & $(0.693)$ & $(0.012)$ \\
\hline \multirow[t]{2}{*}{ Loan Growth $_{t-1}$} & $-0.030 * * *$ & -0.005 \\
\hline & $(0.000)$ & $(0.152)$ \\
\hline \multirow[t]{2}{*}{$R O A E_{t-1}$} & -0.071 & -0.002 \\
\hline & $(0.167)$ & $(0.803)$ \\
\hline \multirow[t]{2}{*}{ LAtoT D $_{t-1}$} & 0.017 & -0.004 \\
\hline & $(0.506)$ & $(0.580)$ \\
\hline \multirow[t]{2}{*}{ Size $_{t-1}$} & 0.245 & 0.141 \\
\hline & $(0.427)$ & $(0.108)$ \\
\hline \multirow[t]{2}{*}{$I_{N C O}$} & $43.349 * *$ & $11.240^{*}$ \\
\hline & $(0.030)$ & $(0.077)$ \\
\hline \multirow[t]{2}{*}{ Loan ratio $_{t-1}$} & 6.976 & 0.047 \\
\hline & $(0.123)$ & $(0.946)$ \\
\hline \multirow[t]{2}{*}{$\operatorname{DESPO}_{t-1}$} & 0.488 & 0.258 \\
\hline & $(0.641)$ & $(0.637)$ \\
\hline \multirow[t]{2}{*}{$N O N I N T_{t-1}$} & -0.073 & -0.009 \\
\hline & $(0.577)$ & $(0.618)$ \\
\hline \multirow[t]{2}{*}{$A G E_{t-1}$} & -0.007 & 0.002 \\
\hline & $(0.528)$ & $(0.197)$ \\
\hline \multirow[t]{2}{*}{ Crisis $_{t}$} & 4.460 & 0.070 \\
\hline & $(0.209)$ & $(0.832)$ \\
\hline \multirow[t]{2}{*}{$M S D_{t-1}$} & -4.060 & $-6.986^{*}$ \\
\hline & $(0.649)$ & $(0.058)$ \\
\hline \multirow[t]{2}{*}{$G D P G R_{t-1}$} & -0.007 & $-0.010^{*}$ \\
\hline & $(0.737)$ & $(0.069)$ \\
\hline \multirow[t]{2}{*}{$l N F_{t-1}$} & $-0.280 * * *$ & -0.005 \\
\hline & $(0.005)$ & $(0.899)$ \\
\hline \multirow[t]{2}{*}{ Constant } & -4.230 & $-2.357 *$ \\
\hline & $(0.397)$ & $(0.070)$ \\
\hline Industry dummies & YES & YES \\
\hline Year dummies & YES & YES \\
\hline $\mathrm{N}$ & 168 & 1079 \\
\hline Log likelihood & -1810.23 & -1030.42 \\
\hline Pseudo $R^{2}$ & 0.094 & 0.062 \\
\hline
\end{tabular}

Notes: The table reports the probit regression estimates of banks' propensity to securitize assets for within subsamples tests for organizational religiosity (Religious adherent versus conventional banks subsamples) during the sample period 2003-2012. All explanatory variables are lagged 1 year. Standard errors of estimated coefficients are clustered at the bank level. *, **, *** stand for statistical significance at the $10 \%, 5 \%$, and $1 \%$ levels, respectively. Variables definitions in Table (2). 
(1) (2)

VARIABLES

Country Governance

Ownership Types

$\mathbf{G R}_{\boldsymbol{j}}$

$-1.278^{*}$

$-0.381^{*}$

$\mathbf{O R}_{\mathrm{i}}$

(0.092)

$1.087 * *$

$(0.015)$

$C A R_{t-1}$

0.029

$(0.255)$

0.018

$(0.416)$

0.006

(0.630)

1.619

(0.566)

0.004

(0.159)

$-0.011$

(0.727)

$-0.016^{* *}$

(0.022)

$-0.016$

(0.150)

$-1.641^{*}$

(0.089)

$-1.219$

(0.923)

$-2.740 * *$

(0.033)

$1.172 * * *$

(0.000)

$-0.000$

(0.996)

$M S D_{t-1}$

GDPGR $_{t-1}$

$-14.980 * * *$

(0.007)

0.001

(0.945)

0.003

(0.939)

$-0.052 * *$

(0.029)

0.014

(0.319)

$-0.054$

(0.720)
(0.000)

$0.808^{*}$

(0.050)

0.030

(0.269)

0.023

(0.231)

$0.012 * * *$

(0.001)

$-0.117 * * *$

(0.008)

0.003

$(0.042)^{* *}$

$-0.015$

(0.627)

$-0.014$

(0.102)

$-0.021$

(0.138)

$-1.016$

(0.265)

$-6.303$

(0.717)

$-2.064$

(0.150)

$0.893 * * *$

(0.000)

0.001

(0.788)

$-8.484 *$

(0.081)

0.004

(0.703)

$-0.007$

(0.851)
0.233

(0.620)

1.046

(0.378)

$-0.612$ 
(0.179)

$G O V_{-} O W N_{t-1}$

$F O R_{-} O W N_{t-1}$

Constant

Industry dummies

Year dummies

$\mathrm{N}$

Log likelihood

Pseudo $R^{2}$

Notes: The table reports the probit regression separate estimates of banks' propensity to securitize assets for Model (1) controlling for country governance indicators and Model (2) controlling for different ownership types for the full sample. All explanatory variables are lagged 1 year. Standard errors of estimated coefficients are clustered at the bank level. *, **, *** stand for statistical significance at the $10 \%, 5 \%$, and $1 \%$ levels, respectively. Variables definitions in Table (2). 